\title{
Germination of Jacaranda mimosifolia (D. Don - Bignoniaceae) Seeds: Effects of Light, Temperature and Water Stress
}

Fábio Socolowski* and Massanori Takaki

Departamento de Botânica; UNESP; C. P. 199; 13506-900; Rio Claro - São Paulo - Brazil

\begin{abstract}
Investigations were carried out to study the effect of light, temperature and water stress on the gemination of seeds of Jacaranda mimosifolia which showed the minimum and maximum germination temperature at 15 and $40^{\circ} \mathrm{C}$, respectively. The optimum temperature was $25^{\circ} \mathrm{C}$ with high percentage and germination rate. Slight promotive effect of white light was observed. Under water stress conditions the effect of light was high but at optimum temperature no effect of light was observed. At -0.9MPa few seeds germinated.
\end{abstract}

Key words: Jacaranda mimosifolia, seed germination, phytochrome, water stress, light sensitivity

\section{INTRODUCTION}

Disturbes in the canopy of tropical forests with formation of gaps of several sizes is responsible for changes, especially in the light environment, resulting in changes in light quality, temperature and soil humidity (Everham III et al., 1996). Plants have the capacity to monitor light quality and fluence, direction and duration and to adjust their development and reproduction to seasonal and daily changes (Furuya and Kim, 2000). That capacity is due to the phytochrome system which is used by pioneer species to detect gaps of the forest canopy and is responsible for induction of seed germination and seedling developmental processes (Vazquez-Yanes and Orozco-Segovia, 1985). This is made by detection of red:far red (R:FR) light ratio by phytochrome $\mathrm{B}$, which is the pre-existing form of phytochrome in seeds (Casal and Sánchez, 1998). The direct sun light shows $\mathrm{R}: \mathrm{FR}$ ratio of 1.2 but under canopy this ratio diminishes due to the differential absorption of $\mathrm{R}$ light by chlorophyll (Smith, 2000).

All seeds have phytochrome and the light sensitivity is due to the form of phytochrome present in then (Takaki, 2001). When seeds have phytochrome A, they can germinate under both light and darkness and if phytochrome B is present the seeds germinate only under light. The light sensitivity of seeds is dependent of incubation temperature as demonstrated by Kendrick (1976) with different batches of Lactuca sativa cv. Grand Rapids.

There is not enough data about light and temperature effects on seed germination of tropical forest species (Leal Filho and Borges, 1992). Studies on the responses of seeds and the characterization of phytochrome involvement in the control of the process are important to support revegetation programs. Jacaranda mimosifolia (with following synonims: Jacaranda ovalifolia and Jacaranda chelonia, Gentry, 1992) is

\footnotetext{
${ }^{*}$ Author for correspondence
} 
considered as a pioneer species (Grau et al., 1997) due to its presence in all succession processes of a secondary forest during 50-year study at the northwest of Argentina. In Brazil, Jacaranda mimosifolia is widely used for urban arborization and as an ornamental plant in parks. However, there is a lack of informations about the germination control. The aim of this work was to study the effects of temperature, light and water stress on seed germination of Jacaranda mimosifolia.

\section{MATERIAL AND METHODS}

Seeds of Jacaranda mimosifolia (D. Don) used in this study were collected from 11 plants found at UNESP, Campus of Rio Claro, São Paulo, Brazil, and immediatly stored in stoppered glass bottles at $5^{\circ} \mathrm{C}$. Twenty-five seeds for each of four boxes on two layers of water soaked filter papers were used throughout. The isothermic incubations $\left(10-40^{\circ} \mathrm{C}\right)$ were carried out inside germinators (FANEM, Brasil). White light was obtained from two $15 \mathrm{~W}$ Philips daylight fluorescent lamps and for dark incubations black boxes were used throughout. Dark germinated seeds were scored under dim green safe light (Amaral-Baroli and Takaki, 2001). For the study of water stress effects, different water potentials were obtained according to Michel (1983) using polyethylene glycol 6000 at 20,25 and $30^{\circ} \mathrm{C}$. Seeds with $1 \mathrm{~mm}$ long roots were considered as germinated. The germination percentage and germination rate were calculated as described by Labouriau and Agudo (1987). The arcsin of germination percentage was submitted to Tukey tests at $\alpha=5 \%$. Two ways of analysis of variance was done according to Zar (1999) using SAS 6.12. Minimum Significant Differences (MSD) for Tukey's Studentized Range (HSD) test were calculated and put on the figure legends.

\section{RESULTS AND DISCUSSION}

Seeds of Jacaranda mimosifolia showed the minimum temperature of germination at $10^{\circ} \mathrm{C}$ and the maximum at $40^{\circ} \mathrm{C}$, according to the definition of Mayer and Poljakoff-Mayer (1989) which were the temperatures where seeds could germinate. Although no significant differences were found in the range of 20 to $30^{\circ} \mathrm{C}$ for final percentage germination, the highest germination rate was found at $25^{\circ} \mathrm{C}$ indicating the optimum temperature (Figs. 1A and 1B).

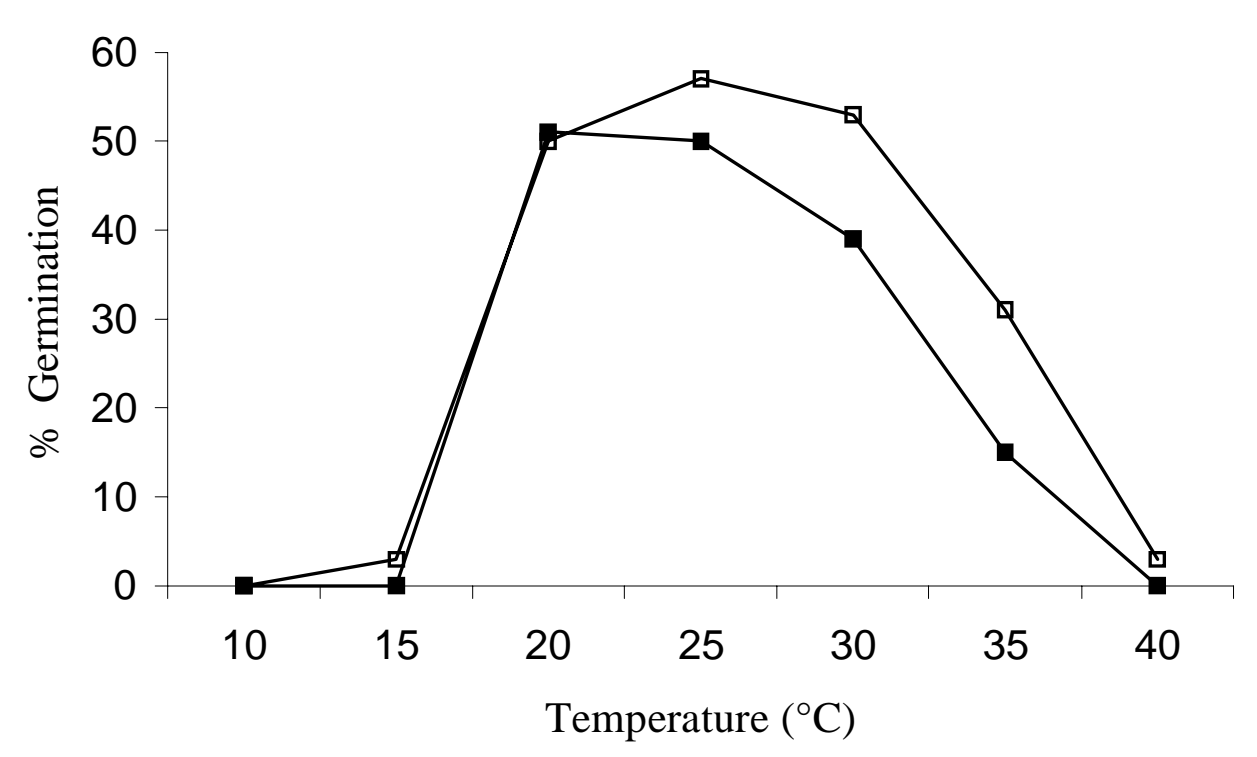




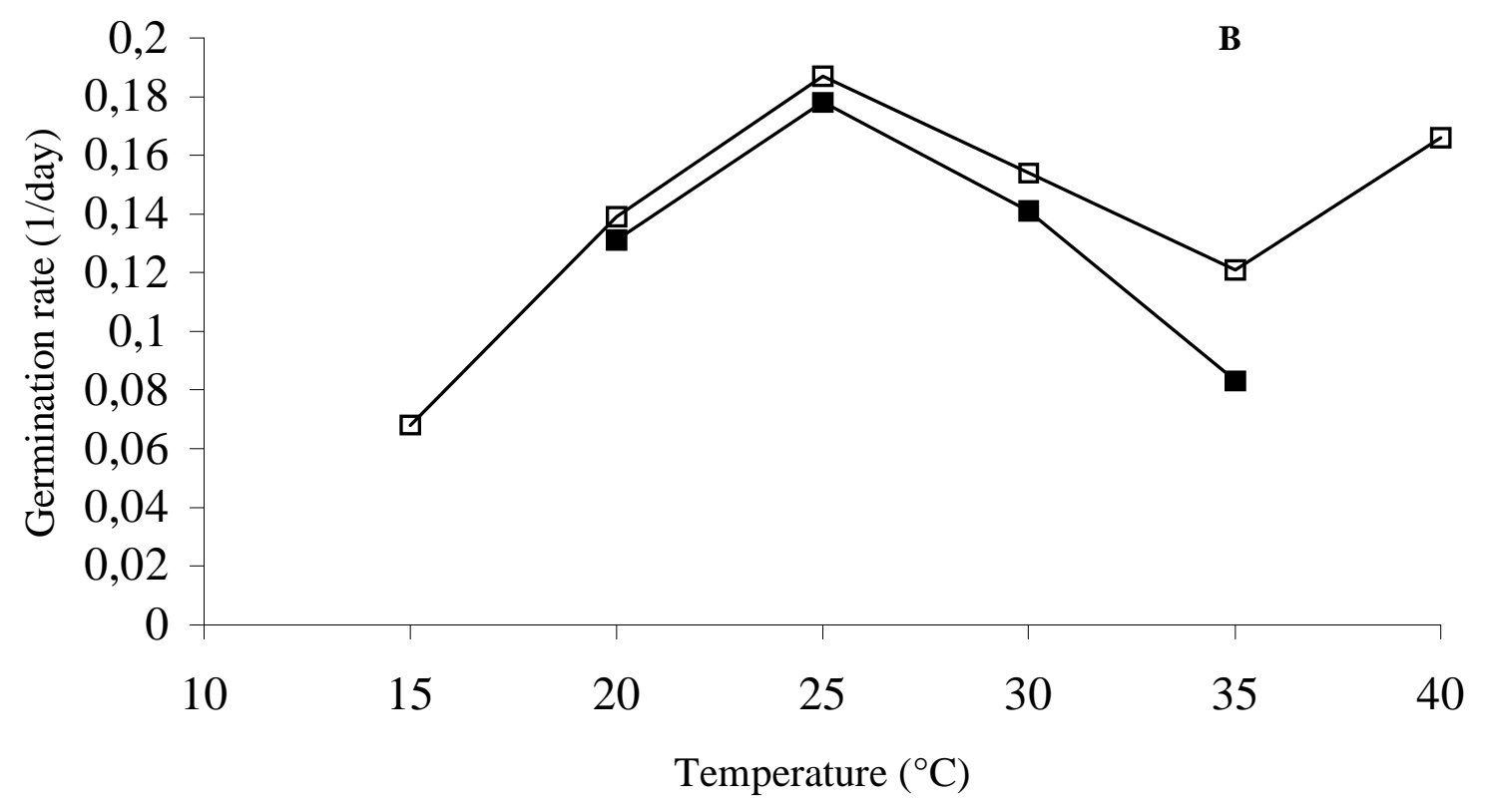

Figure 1 - Effect of light and temperature on germination of seeds of J. mimosifolia (D. Don Bignoniaceae) Seeds end temperature on germination of seeds of J. mimosifolia, $\mathbf{\square}$ seeds germinated in dark and $\square$ seeds germinated in light. MSD for germination percentage at $\alpha=0.05$ for temperature effect $=10.72 \%$ and for light effect $=3.73 \%$. MSD for germination rate at $\alpha=0.05$ for temperature effect $=0.04$ and for light effect $=0.014$.

The light incubation resulted in slight induction of germination in the range of temperature of 20 to $35^{\circ} \mathrm{C}$, with statistical differences. This result indicated a possible participation of phytochrome $\mathrm{B}$ in the control of seed germination in Jacaranda mimosifolia (Takaki, 2001). It also meanst that seeds of Jacaranda mimosifolia could germinate in different light environments, as open areas and in the dark, buried in the soil. The light requirement for seed germination has been reported for pioneer species, although Cecropia obtusifolia and Piper auritum seeds germinated in the dark under alternating temperatures (VázquezYanes and Orozco-Segovia, 1985). The dark germination of seeds indicated Jacaranda mimosifolia seeds have pre-existing Pfr enough to induce germination in the dark (Casal and Sanchez, 1998).

The temperature range where seeds of Jacaranda mimosifolia germinated was the same as for several tropical species (Miranda and Ferraz, 1999; Nassif and Perez, 2000; Válio and Scarpa, 2001). The optimum temperature was in accordance with
Copeland and McDonald (1995) who reported that usually it was between 15 and $30^{\circ} \mathrm{C}$.

Seeds of Jacaranda copaia germinated more in open areas than under canopy and their seedlings could not survive more than seven months under shade light (Guariguata, 2000). The direct sun light irradiation on soil surface in gaps of the canopy and in open areas resuled in changes in the temperature and soil humidity (Everham III et al., 1996). The low soil humidity was responsible for the decrease in the number of germinating seeds and increase in the seedlings mortality due to the low water potential under this condition. The light sensitivity interacted with water stress in several species (Takaki, 2001). Usually light insensitive seeds under water stress conditions germinated better under darkness and Takaki (2001) proposed that phytochrome A was reponsible for that control of germination.

When seeds of Jacaranda mimosifolia were submitted to water stress of $-0.9 \mathrm{MPa}$, only $3 \%$ of seeds germinated under white light and no germination occurred in darkness (Fig. 2). However, at $-0.6 \mathrm{MPa}$ the percentage of 
germination was lower under darkness than under white light at $20^{\circ} \mathrm{C}$ and no differences were found in the germination velocity under light and darkness. When seeds of Jacaranda mimosifolia were submitted to water stress at $25^{\circ} \mathrm{C}$, no significant differences were observed between light and dark treatments and no germination occurred at $-0.9 \mathrm{MPa}$. The germination rate also did not show significant difference between light and darkness incubations (Fig. 3).

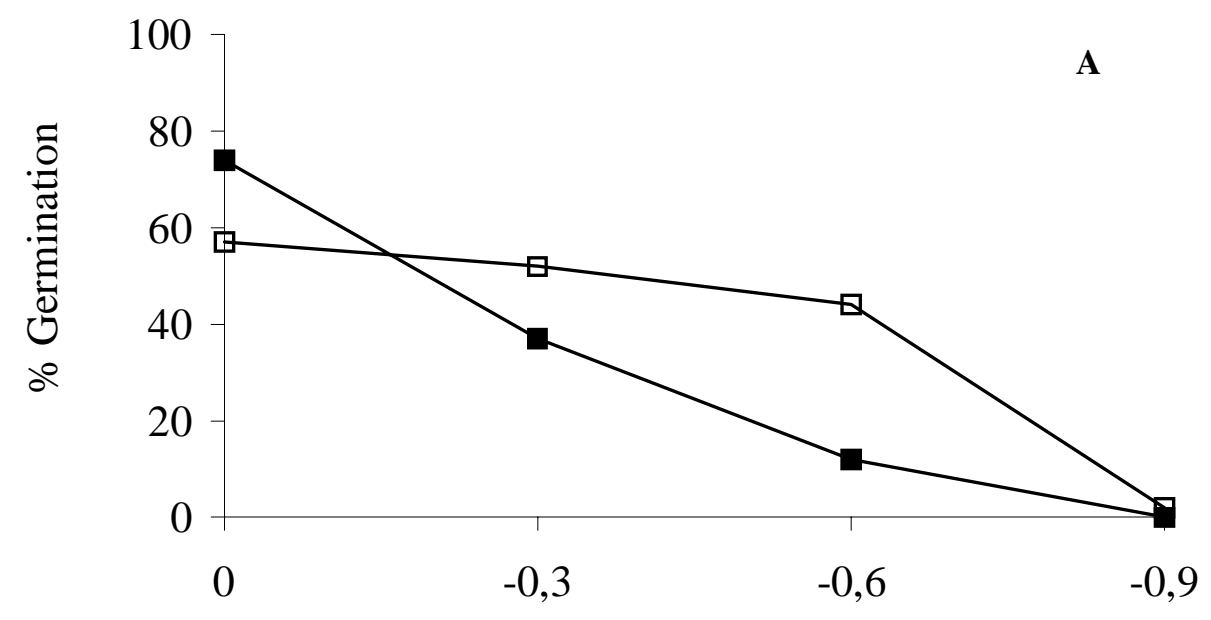

Water potential (MPa)

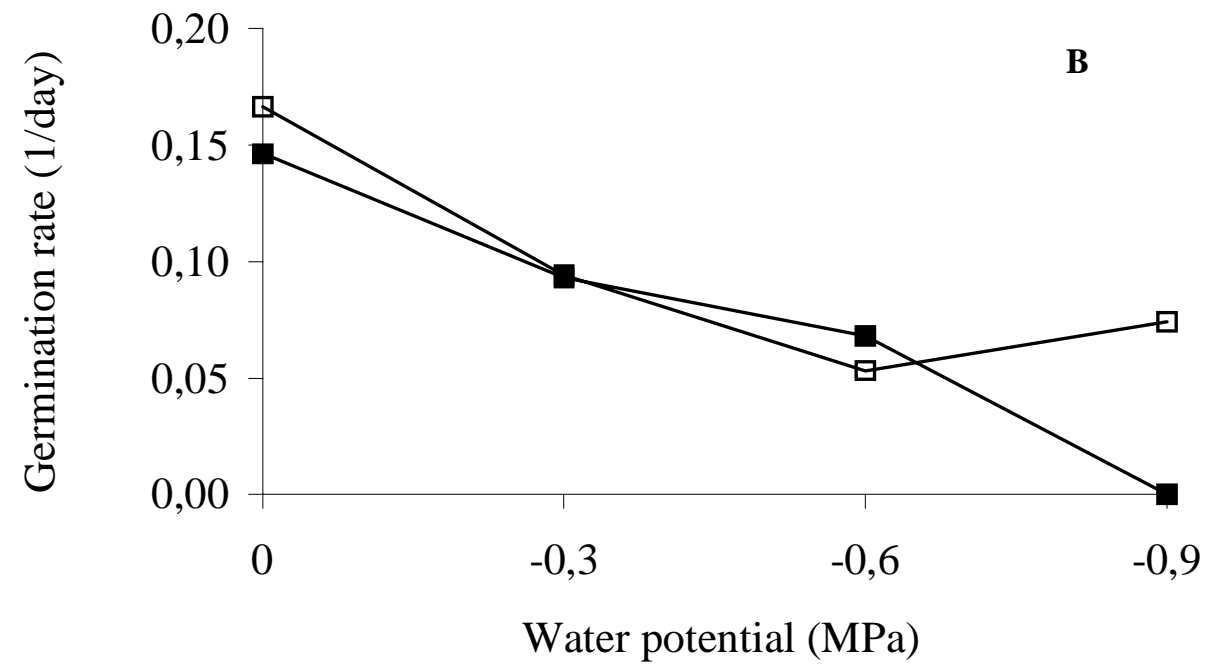

Figure 2 - Effect of water potential on percentage and germination rate of Jacaranda mimosifolia seeds at $20^{\circ} \mathrm{C}$, $\square$ seeds germinated in dark and $\square$ seeds germinated in light. MSD for germination percentage at $\alpha=0.05$ for water potential effect $=10.48 \%$ and for light effect $=5.54 \%$. MSD for germination rate at $\alpha=0.05$ for water potential effect $=0.02$ and for light effect $=0.012$. 

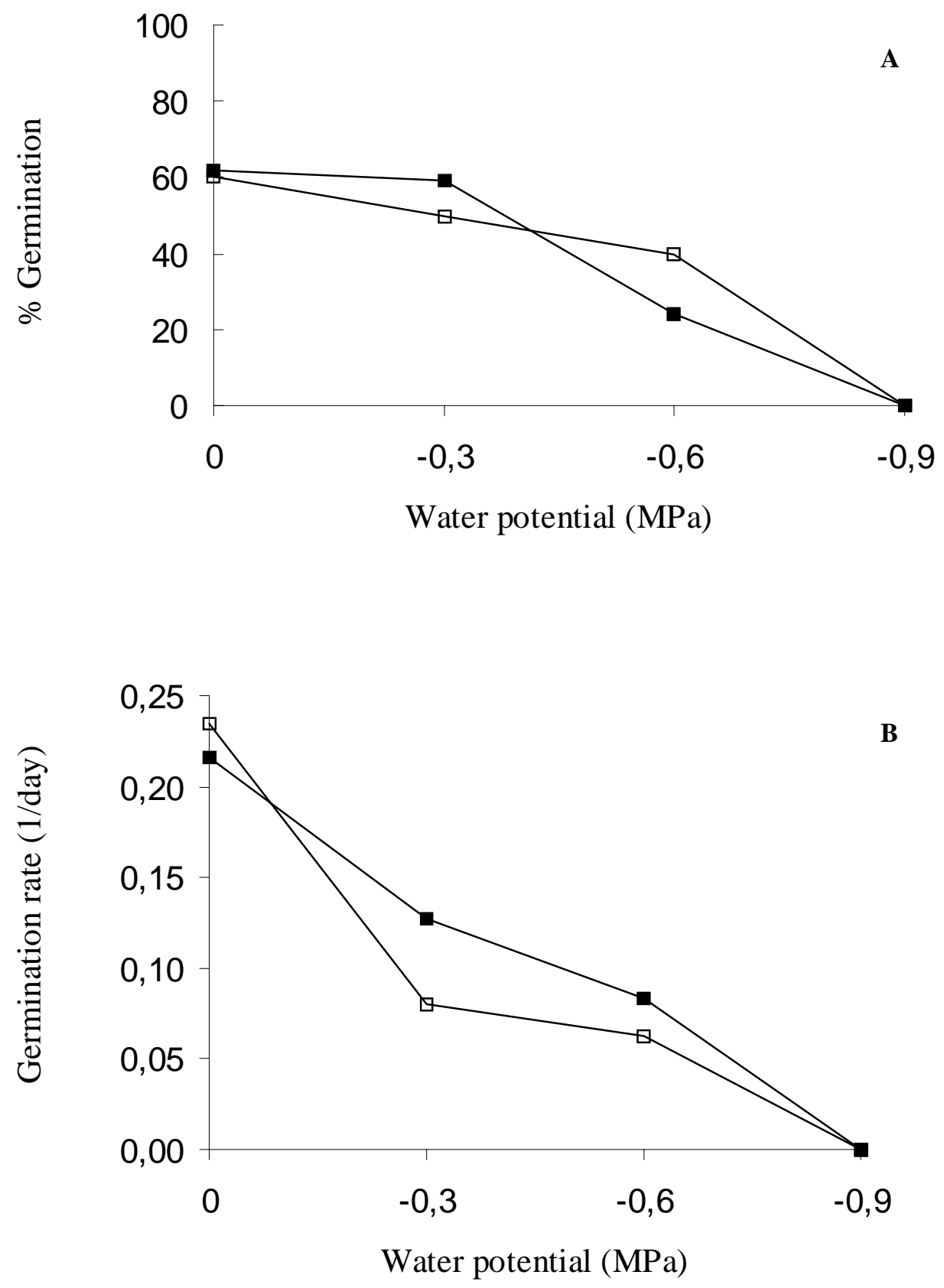

Figure 3 - Effect of water potential on percentage and germination rate of Jacaranda mimosifolia seeds at $25^{\circ} \mathrm{C}$, seeds germinated in dark and $\square$ seeds germinated in light. MSD for germination percentage at $\alpha=0.05$ for water potential effect $=10.24 \%$ and for light effect $=5.41 \%$. MSD for germination rate at $\alpha=0.05$ for water potential effect $=0.01$ and for light effect $=0.005$.

Seeds of Jacaranda mimosifolia submitted to water stress at $30^{\circ} \mathrm{C}$ presented light sensitivity in almost all water potential tested, except for $-0.9 \mathrm{MPa}$ where very low percentage of seeds germinated and the comparison of germination rates indicated that no differences were found between light and dark incubations (Fig. 4). 

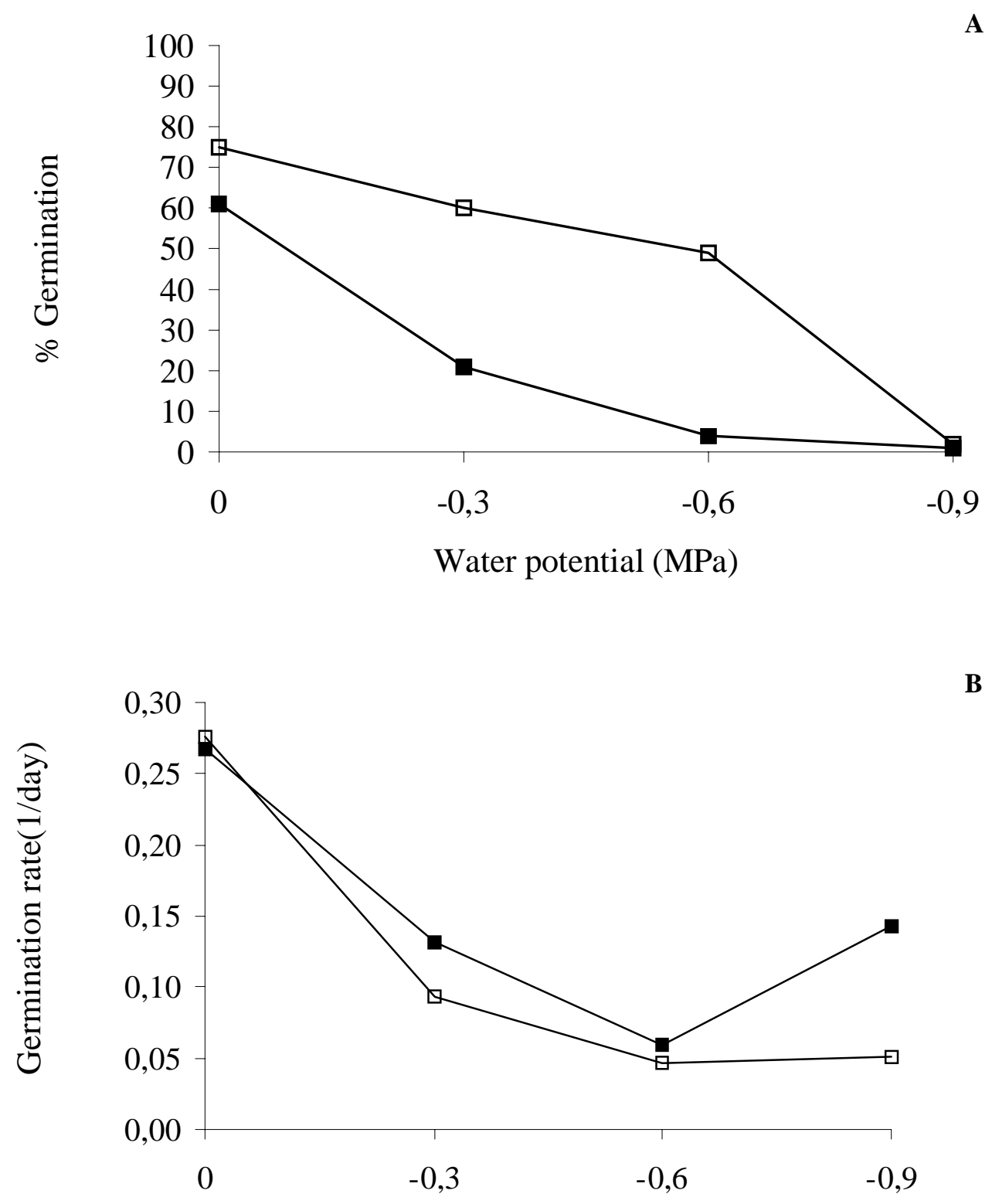

B

Water potential (MPa)

Figure 4 - Effect of water potential on percentage and germination rate of Jacaranda mimosifolia seeds under different condition of light at $30^{\circ} \mathrm{C}$, $\mathbf{m}$ seeds germinated in dark and $\square$ seeds germinated in light. MSD for germination percentage at $\alpha=0.05$ for water potential effect $=9.47 \%$ and for light effect $=5.01 \%$. MSD for germination rate at $\alpha=0.05$ for water potential effect $=0.047$ and for light effect $=0.025$.

Seeds of Adenanthera pavonina showed germination under near the same range of water potential at $30^{\circ} \mathrm{C}$ as observed for Jacaranda mimosifolia. Seeds of Anadenanthera pavonina after scarification germinated only until $-0.4 \mathrm{MPa}$ (Fanti and Perez, 1998).
Our results are in accordance with those of Heydecker (1977), indicating that the increase in the environmental stresses reduces the germination rate of seeds, although the effects of stresses depends not only of genetic constitution but also of physiological conditions of tested seeds. 
Changes in the water potential of the medium alter the properties of the tegument of seeds and low water potential induces low water content of the tegument and consequently low diffusion of water to the inside of seeds (Hadas, 1976). Thus, low absorption of water by seeds occurs, lowering enzyme activities which delays the developmental processes. The reduction in water absorption by seeds under stress conditions seems to be the main factor responsible for decrease in the rate of root growth, respiration and germination (Ashraf and Abu-Shakra, 1978). The delay in the germination can increase the probability of seedling to be in condition which induces development in environment with constant changes (Nassif and Perez, 2000).

Hegarty (1978) reported that the inhibition of germination by low water stress could be named as secondary or induced dormancy since the seeds germinated when the water availability increased. Our results indicated that at optimum temperature light had no effect under water stress condition, but at 20 and $30^{\circ} \mathrm{C}$, the effect of light promoting the germination under water stress was observed, indicating that when the temperature was far from the optimum, phytochrome was used by plants to promote germination.

There is a wide range of temperature in a gap of canopy of a tropical forest and the temperature decreases from the center to the border of the gap while the temperatures are almost constant under the canopy (Vazquez-Yanes and Orozco Segovia, 1985). Phytochrome B is responsible for detection of changes in the R:FR ratio under canopy (Ballaré and Casal, 2000). When seeds of Jacaranda mimosifolia were exposed to water stress the promotion of their germination could be mediated by phytochrome B, although Takaki (2001) proposed that phytochrome A could control the osmotic potential of cell and thus, seed germination under water stress conditions.

Our results indicated that under natural conditions Jacaranda mimosifolia behaved as a pioneer or secondary species of succession with high percentage of germinating seeds in gaps and forest border, where light irradiation was high. However, under canopy where the temperature was low, these seeds could also germinate.

\section{RESUMO}

Sementes de Jacaranda mimosifolia apresentaram temperaturas mínima e máxima de germinação a 15 e a $40^{\circ} \mathrm{C}$, respectivamente. A temperatura ótima foi de $25^{\circ} \mathrm{C}$ com alta porcentagem e velocidade de germinação. Uma pequena estimulação da germinação pela luz foi observada. Sob condições de estresse de água o efeito promotor da luz foi maior, mas na temperatura ótima este efeito da luz não foi observado. No potencial de água de $-0,9 \mathrm{MPa}$ praticamente nenhuma semente germinou.

\section{ACKNOWLEDGEMENTS}

This work was supported by grants from FAPESP and FUNDUNESP. M.T. is a CNPq research fellow.

\section{REFERENCES}

Amaral-Baroli, A. and Takaki, M. (2001), Phytochrome controls achene germination in Bidens pilosa L. (Asteraceae) by very low fluence response. Brazilian Archives of Biology and Technology, 44, 121-124.

Ashraf, C. M. and Abu-Shakra, S. (1978), Wheat seed germination under low temperature and moisture stress. Agronomy Journal, 70, 135-139.

Ballaré, C. L. and Casal J. J. (2000), Light signals perceived by crop and weed plants. Seed Crops Research, 67, 149-160.

Casal, J. J. and Sánchez, R. (1998), Phytocromes and seed germination. Seed Science Research, 8, 317-329.

Copeland, L. O. and Mcdonald, M. B. (1995), Principles of seed science and technology. New York : Chapman and Hall. pp. 59-110.

Everham III, E. M.; Myster, R. W. and Vandegennachte, E. (1996), Effects of light, moisture, and litter on the regeneration of five tree species in the tropical montane wet forest of Puerto Rico. American Journal of Botany., 83, 106-068.

Fanti, S. C. and Perez, S. C. J. G. A. (1998), Efeitos do estresse hídrico, salino e térmico no processo germinativo de sementes de Adenanthera pavonina $\mathrm{L}$. Revista Brasileira de Sementes, 20, 167-177.

Furuya, M. and Kim, C. B. (2000), Do phytochromes interact with diverse partners? Trends in Plant Science, 5, 87-89.

Gentry, A. H. (1992), Bignoniaceae. Flora Neotropica. New York. pt. 2. p. 88-89. 
Grau, H. R.; Arturi, M. F.; Brown, A. D. and Aceñolaza, P. G. (1997), Floristic and structural patterns along a chronosequence of secondary forest succession in Argentina subtropical montane. Forest Ecology and Management, 95, 161-171.

Guariguata, M. R. (2000), Seed and seedling ecology of tree species in neotropical secondary forests: management implications. Ecological Applications. 1, 145-154.

Hadas, A. (1976), Water uptake and germination of leguminous seeds under changing external water potential in osmotic solutions. Journal of Experimental Botany, 27, 480-489.

Hegarty, T. W. (1978), The physiology of seed hydration and dehydration, and the relation between water stress and the control of germination: a review. Plant Cell and Environment, 1, 101-119.

Heydecker, W. (1977), Stress and seed germination: an agronomic view. In: Khan, A. A. The physiology and biochemistry of seed dormancy and germination. New York : North-Holland Publ. Co. pp. 237-282.

Kendrick, R. E. (1976), Photocontrol of seed germination. Science Progress, 63, 347-367.

Labouriau, L. G. and Agudo, M. (1987), On the physiology of seed germination in Salvia hispania L. I Temperature Effects. Anais da Academia Brasileira de Ciências, 59, 37-56.

Leal Filho, N. and Borges, E. E. L. (1992), Influência da temperatura e da luz na germinação de sementes de Canudo de Pito (Maebea fistulifera MART.). Revista Brasileira de Sementes, 14, 57-60.

Mayer, A. M.; Poljakoff-Mayber, A. (1989), The germination of seeds. $4^{\text {th }}$ ed. Oxford, pp. 38-56.

Michel, B. E. (1983), Evaluation of the water potentials of solutions of polyethylene glycol 8000 both in the absence and presence of other solutes. Plant Physiology, 72, 66-70.

Miranda, P. R. M. and Ferraz, I. D. K. (1999), Efeito da temperatura na germinação de sementes e morfologia da plântula de Maquira sclerophylla (Ducke) C. C. Berg. Revista Brasileira de Botânica, 22, 303-307.

Nassif, S. M. L. and Perez, C. J. G. (2000), Efeito da temperatura na germinação de sementes de Amendoim-do-campo (Pterogyne nitens Tul.). Revista Brasileira de Sementes, 22, 1-6.

Smith, H. (2000), Phytochromes and light signal perception by plants - an emerging synthesis. Nature. 407, 585-591.

Takaki, M. (2001), New proposal of classification of seed based on forms of phytochrome instead of photoblastism. Revista Brasileira de Fisiologia Vegetal, 13, 103-107.

Válio, I. F. M. and Scarpa, F. M. (2001), Germination of seeds of tropical pioneer species under controlled and natural conditions. Revista Brasileira de Botânica, 24, 79-84.
Vázquez-Yanes, C. and Orozco-Segovia A. (1985), Posibles efectos de los claros de la selva, sobre la germinación de tres especies de árboles pioneros: Cecropia obtusifolia, Heliocarpus donneell-smithii y Piper auritum. In: Investigaciones Sobre la Regeneración de Selvas Altas en Vera Cruz, México., México-Printed. cap. 11. pp. 241-253.

Zar, J. H. (1999), Biostatistical Analysis. Englewood Cliffs, New Jersey : Prentice Hall. pp. 312.

Received: February 19, 2003; Revised: October 03, 2003; Accepted: March 05, 2004. 